\title{
Grundtvig og de latinske salmer - et teologisk perspektiv
}

\author{
Af Lars Thunberg
}

Emnet er vanskeligt. Hvad jeg kan tilbyde, er kun fragmentariske kommentarer. Jeg vil begynde med at markere nogle reservationer og antyde min fremgangsmåde. I Grundtvig Studier 1959 skrev Jørgen Elbek afhandlingen »Grundtvig og de latinske hymner«, som stadig er den helt afgørende fremstilling set ud fra historiske, litterære og i høj grad også teologiske synspunkter. Dette anerkender også Jørgen Pedersen, selv om han har kritiske bemærkninger. ${ }^{1}$ Elbeks artikel svarer på en overbevisende måde til hans bog fra 1960: Grundtvig og de graske salmer. ${ }^{2} \mathrm{Jeg}$ vil derfor kun diskutere nogle enkeltheder - i teologisk perspektiv - i den anskuelse/vision, som Grundtvig giver udtryk for i sine gengivelser, sammenlignet med de perspektiver, som de originale tekster angiver. I øvrigt har jeg haft glæde af tre afsnit om Grundtvig-salmer med latinsk baggrund i Kr. Tårups bog Grundtvigs påskesalmer (1937) ${ }^{3}$ og Chr. Thodbergs artikel »Grundtvig som salmedigter « i det store samleværk Grundtvig og grundtvigianismen $i$ nyt lys (udgivet i jubilæumsåret 1983 af Det danske Samfund). ${ }^{4}$ Vigtige som almindelig baggrundslæsning har også været Niels Thomsens artikel i samme værk: »Grundtvig i oldkirkens spejl« og J.H. Schjørrings bog »Grundtvigs billedsprog - og den kirkelige anskuelse « (fra 1990). ${ }^{5}$

En anden reservation gælder de latinske tekster, som jeg har brugt. Elbek har påvist, at Sang-Værkets gendigtninger næsten allesammen går tilbage til Chlictoveus' Elucidatorium fra 1517. Jeg har imidlertid, af praktiske grunde, ikke været i stand til at bruge denne tekst. I detaljerne er det selvfølgelig vigtigt at bruge den tekst, som Grundtvig har brugt, men når det gælder det teologiske, synes jeg ikke, at det er helt afgørende. Jeg har været nødt til at holde mig til H.A. Daniel: Thesaurus Hymnologicus I-V (1841-56). Fra denne udgave har jeg hentet de relevante tekster. En sammenligning mellem disse tekster og 
Elucidatorium synes at vise, at der fra teologisk synspunkt ikke var helt afgørende forskelle.

En tredje reservation gælder udvalget. Jeg har ikke haft mulighed for at beskæftige mig med alle Grundtvigs gendigtninger. Jeg har valgt 14 af dem. Teksterne spænder over et bredt felt med hovedvægt ved Jul, Påske og Pinse samt Kirken. Desuden indgår nogle af de mest velkendte latinske hymner $\mathrm{i}$ dette udvalg.

Ud fra disse begrænsninger har jeg også lavet min disposition. Jeg vil først nævne et grundproblem, når det gælder Sang-Værkets hensigt og de latinske hymners placering deri. Dette grundproblem fremhæver Elbek meget stærkt. For det andet vil jeg prøve at give en overfladisk karakteristik af Grundtvigs teksters forhold til de latinske indholdsmæssigt set (de metriske og stilistiske overensstemmelser har Elbek analyseret på en fornem måde, og dem vil jeg ikke tage op her, selv om litterær stil og indhold ligger meget tæt op ad hinanden). Det tredie - og det store afsnit - bliver så en kort gennemgang af 10 salmer. Denne gennemgang kan kun pege på nogle få enkeltheder, der synes at have teologisk relevans.

\section{A. Et grundproblem omkring Grundtvigs Sang-Vark og de latin- ske hymners rolle}

Grundtvigs Sang-Værk er en enestående bedrift i kristenhedens hymnehistorie. Dets hensigt er ikke bare »alsidig opbyggelse og historisk overskue «. Det gør - med Elbeks ord - krav på at være »den nutidige danske menigheds entonige Lovsang «. ${ }^{6}$ Nutidigheden og entonigheden er lige så vigtige. Den kirke, der består, er den levende menighed. Det er den nulevende (danske) menighed, der i sig optager den samlede tone af kristenhedens lovsang gennem historien. Ud fra denne integrative indoptagelse er et hovedsynspunkt i Sang-Værket givet: det er de syv folkemenigheder (i Grundtvigs forstand), som kommer til orde: den hebraiske, den græske, den latinske, den engelske, den tyske og den danske (nordiske), hvortil så skal lægges den syvende, endnu ikke kendte, (alt sammenfattende) menighed, som Grundtvig først i Christenhedens Syvstierne antyder kunne være den indi- 
ske. (Jeg vil ikke her gå ind på dette lidt bizarre problemkompleks, præget af Grundtvigs historiesyn og - også - hans dermed forbundne vestlige arrogance). Sang-Værket skulle føje dem sammen til én tone.

Både Thodberg og Elbek citerer i denne sammenhæng Grundtvigs brev til Ingemann i forbindelse med udgivelsen:

Hvad der især glæder mig ved det, er den sammensmeltning af Toner fra alle Hovedgangene $\mathrm{i}$ den almindelige Kirke, som under udarbejdelsen naaede mit Øre og rørte mit Hjerte; og skjønt jeg nok kan vide, at de forskjellige Toner ved at gaa igjennem mig har tabt meget af deres Ejendommelighed, tør jeg dog haabe, der er spor tilbage, der vil fryde troende Sjæle som Forbud paa den ny Sang, hvormed alle Stammer og Tungemål prise ham, af og ved og til hvem alle Ting er $\ll$.

Hvis man holder fast ved dette, betyder det, at tonerne er forskellige, men at de, når de nu formidles gennem Grundtvigs gendigtning, mere og mere samler sig til én tone. Det indebærer naturligvis ikke, at Grundtvig mener, at Sang-Værket allerede rummer den samlede (nærmest eskatologisk forståede) harmoni, men det peger hen imod den. Hans perspektiv er her klart $\emptyset$ kumenisk. Den aktuelle kirkesang samler i sig de forskellige menigheders kirkesang til en højere enhed. Derved bliver gengivelsen af de latinske hymner en del af denne proces, og disse hymner bidrager til at udtrykke den universelle kirkes harmoni i lovsangen.

Så langt, så godt. Men nu komplicerer Elbek sagen stærkt i sin artikel. Han sammenligner nemlig, hvad der står i brevet til Ingemann og et samtidigt brev til Gunni Busck samt en anmeldelse, Grundtvig har skrevet, af Fengers udgivelse (i 1827) af Kingos Psalmer og aandelige Sange fra 1828, og finder, at her møder man en dialektik, som måske er uforløst, men som alligevel peger $\mathrm{i}$ retning af et mere skeptisk forhold til universalitetssynspunktet. Salmisten skal tolke sin tro, som er kristendommens fælles tro, men det kan han kun gøre i samme grad, som han tolker sit timelige jeg, produktet af hans særegne arv og milieu, siger Elbek. Sidstnævnte er, hvad Grundtvig kalder 
»den konstige Natur«, men jo mere denne nødvendighed understreges, jo mindre bliver man delagtig i kristenhedens universelle fællesskab. Ud fra det høje udgangsprincip gælder således, iflg. Elbek, den paradoksale sætning: at »jo bedre salmer han skriver, des dårligere salmer skriver han «. ${ }^{7}$ »Den konstige Natur «'garanterer en form for ægthed, men udelukker samtidig den universelle gyldighed.

Hvad medfører dette så for gendigtningernes vedkommende? Jo, de bliver til forvanskninger, og samtidig må de selv overholde reglerne for »den konstige Natur«. Elbeks pessimistiske slutning, som han vel gør gældende for Grundtvigs vedkommende, bliver da følgende: »gendigtningerne tilhører ikke den hele kristenhed, men en snævrere menighed, en dansk-latinsk eller en dansk alene. Ingen kristen kan tale $\mathrm{i}$ den almindelige kirkes navn. Ingen salmedigter kan fremføre den universelle lovsang «. ${ }^{8}$

Dette er et grundproblem - og en hypotese - som vi må diskutere. Hvis vi accepterer hypotesen, er der nogle slutninger, som vi må drage for den latinske hymnedigtnings og for Grundtvigs gendigtnings vedkommende:

1. Den latinske hymnedigtning har sin styrke i en egenart, som ikke kan overføres og heller ikke repræsenterer den sande universalitet;

2. Grundtvigs gendigtning udgør en overføring af ansatser fra den latinske hymnedigtning, som svarer til Grundtvigs og hans samtids egenart, men ikke til mere. Denne bliver ikke mere universel af den grund. Den bliver kun fordansket.

3. Hverken original eller gendigtning, og heller ikke nogen form for sammensmeltning mellem dem, repræsenterer den universelle lovsang.

4. Kan man alligevel tænke sig, at sammensmeltningen gør Sang-Værk mere universelt, end hvis den ikke var der?

5. Er den universelle lovsang $i$ en vis forstand summen af det hele eller kun en eskatologisk størrelse?

Til dette med »den konstige Natur « må føjes problemet om Grundtvigs forståelse af de syv menigheder. I Christenhedens Syvstierne (1854), som er Grundtvigs modne udtryk for en tænk- 
ning, som han har udfoldet siden 20-erne, dominerer jo i høj grad, hvad vi kunne kalde det pessimistiske eller det negative perspektiv. Dette gælder ikke mindst billedet af "Latiner-Menigheden«. I forbindelse med Sang-Værk fornemmer læseren meget af en opdagelsens glæde hos Grundtvig over hymnernes udtryk for »Latiner-Menighedens« lovsang. Næsten intet af dette er tilbage her i »Syvstiernen«. Jeg har prøvet at gennemgå, hvilke positive udsagn der findes om denne menighed i denne sang; det er ikke mange. Det vigtigste siges måske i strofe 4 , hvor det hedder: "Troen, som den randt af Rode, / Fast Du holdt i Jesu navn « (Latinermenigheden er altså Troens menighed). I strofe 36 tales videre om, at Gud nu vil samle katholikker og protestanter til det samme Gæstebud. Ellers prædiker Grundtvig for »Latiner-Menigheden «, oplærer den og venter på dens omvendelse, men lærer egentlig intet fra den. (Grækermenigheden bedømmes $\mathrm{i} \emptyset v$ rigt næsten lige så hårdt.)

Vi skal ikke blande disse ting sammen, men mit spørgsmål er: Er den inspiration, som han så åbenbart en gang fik fra de latinske hymner (som fra de græske) nu glemt, og har den ingen betydning for synet på »Latiner-Menigheden « (som de var en unægtelig del af)? Eller er det den af Elbek markerede pessimisme ud fra »den konstige Natur«, som gør dem irrelevante som udtryk for denne menighed?

B. Nogle almindelige trak ved Grundtvigs gengivelse af latinske hymner

Lad os først slå den store betydning fast, disse gengivelser har i Grundtvigs Sang-Værk. Nogle af de bedste og mest overbevisende af Grundtvigs salmer hviler på latinske hymner. Dette kan ikke være en tilfældighed. Elbek antyder, at han dér for sit eget vedkommende fandt noget, som den datidige danske salmedigtning lod uforløst, at: »Hans interesse for de latinske hymner har sin rod i et valgslægtskab «. ${ }^{9}$ Elbek tilføjer dog, at Grundtvig måske har tænkt sådan, men han har aldrig udtalt det! Sidstnævnte kan være sandt. Men man kan ikke se bort fra følelsen af en frigørelse, udløst af disse hymner (hvilket ikke mindst kommer til udtryk metrisk, hvor Grundtvig i forbavsende grad er 
trofast på trods af de danske sproglige betingelser), en udvidelse af perspektiverne. Ikke sådan, at han slet ikke skulle rumme disse perspektiver $\mathrm{i}$ forvejen, men den teologi- og salmetradition, som han var mest hjemme i, hæmmede dem. Dette gælder sandsynligvis i endnu højere grad om mødet med Irenæus og med den græske hymnedigtning.

Dette betyder dog ikke, at gendigtningen ikke rummer en meget kompleks kombination af tilknytning/troskab, afstandtagen og forandring/forskydning. Her kan jeg blot antyde noget af dette rent generelt. Når man gennemgår de enkelte salmer, kan man nemt genfinde det.

Tilknytning/troskab finder man først og fremmest i hymnens ansats, i det perspektiv, som begyndelsesordene eller grundtonen angiver. Dette er ofte af naiv/bibelsk karakter, som både havde tiltrukket tidligere generationer af gendigtere og sikkert også Grundtvig, som i de første strofer tit kunne finde udtryk for trosbekendelsens genuine tro: Veni redemptor gentium, Puer natus in Bethlehem, Stabat mater dolorosa, Mane prima Sabbati, Surrexit Christus hodie, Urbs beata Ierusalem, etc. Det drejede sig ikke bare om læredigte på vers, men om en direkte fromhed, som gik til troens indhold på en umiddelbar måde.

I dette finder Grundtvig tit en frihed til at være sig selv, samtidig med at han falder ind i kirkens kor. Hvor meget han end elskede Kingo, var dennes lutherske ortodoksi stedvis vanskelig at tolerere. Thodberg har peget på, hvordan en løsrivelse fra Kingo begynder allerede i 20 -erne og fuldføres i 30-erne..$^{10}$ Det er ikke en stiv frelsesorden, der skal beskrives, men frelsesgerningens resultat, der skal lovsynges som det menneskeliges genfindelse af sig selv.

Uden i øvrigt at gå ind på enkeltheder i Grundtvigs forhold til Kingo, er det vigtigt at slå fast, at de latinske hymner i deres ansats har betydet en frigørelse i Grundtvigs salmedigtning.

Den afstandtagen fra forlægget, som man kan lægge mærke til i enkelte tilfælde, hænger nøje sammen med tiltrækningen. Det er netop der, hvor de latinske hymner bliver dogmatiserede på en steril måde (formaliserende, stereotypt, også i rimopbygningen og versenes antiteser), at Grundtvig må melde fra. Dette betyder nu tit, at han kan gå glip af teologiske pointer i sine forlæg. Det indebærer en afstandtagen med henblik på stil (med teologiske 
konsekvenser), men der findes også en klar afstandtagen fra romersk-katolske lærepunkter. Både den romersk-katolske kirke og Grundtvig ærer Jomfru Maria og har en mariologi, men ikke den samme. For Rom er Maria først og fremmest et led i et frelsesskema, for Grundtvig er hun en »mø» (som han gerne siger), som bliver udvalgt til underfuldt, på vore vegne, at bære Guds egen Søn til jordelivet. Et andet punkt er fortjenestelæren. Hvor den antydes i hymnerne (men det sker ikke tit), ser Grundtvig væk fra den. I de fleste andre tilfælde kommer Grundtvig dog ikke i strid med de romersk-katolske lærepunkter, fordi de hymner, han vælger, ikke er specielt optaget af dem. Deres indhold er de bibelske hovedbegivenheder og den liturgiske fejring af disse. Dette passer godt til Grundtvigs eget anliggende.

Dette betyder, at mens en direkte afstandtagen ikke er så fremtrædende, så er forandring/forskydning desto vigtigere. Der findes åbenbare perspektivforskydninger, som ikke så meget skyldes dogmatiske forskelle som Grundtvigs personlige temperament og præferencer. Grundtvig kan fanges af ét motiv og udbygge det uden hensyn til grundtekstens sammenkobling af dette med andre. Dette kan have en teologisk begrundelse, fordi Grundtvig jo ikke går væk fra sine egne teologiske overbevisninger og derfor gerne læser dem ind $\mathrm{i}$ den tekst, han gengiver. Dette kan gælde henvisninger til dåb og nadver eller til det kirkelige fællesskab, hvor hentydninger til en institutionalistisk forståelse undgås.

Elbeks tale om »valgslægtskab « er for mig at se betydningsfuld. Hvad Grundtvig vælger, har han tit en spontan tilknytning til. Dette betyder, at der ikke er så mange konflikter mellem ham og den tekst, som han gengiver. Afvigelserne har en anden grund end konflikt. Men hans præferencer gør sig gældende: dels i de tekster, som han vælger, dels i hans måde at gengive dem på. Et ufravigeligt punkt er i denne sammenhæng det teologiske forhold, at han fremhæver korsbegivenheden som en sejr og Kristus som helt (ikke som offer), og dermed Djævelens nederlag og livets fødsel på ny i påskens under. Ifølge min opfattelse stemmer Grundtvig på disse punkter nøje overens med den $\emptyset$ stlige kristenhed. Hvor disse motiver findes i originaltek- 
sten, fremhæver Grundtvig dem endnu mere; hvor de ikke findes, føjer han dem ofte til.

Et andet punkt er sammenføringen af naturiagttagelse og kristen livsopfattelse. Naturen er delagtig i påskens opstandelsesglæde. Et tredje punkt er naturligvis fortolkningen af Pinsen som det levende Ords tilstedeværelse hos os, tilgængeligt for alle folkeslagene. I det hele taget forstærkes eller indskydes Ordets betydning i gendigtningen.

Sammenfattende kan man sige om forskydningerne: større fremhævelse af den bibelske konkretion, stærkere betoning af forbindelsen mellem det, som vi kan iagttage i naturen, og de åbenbarede sandheder; en vis psykologisering af Gudsforholdet og en eksistensialisernig af de nedarvede formler, samt et fors $\emptyset \mathrm{g}$ på at gøre det lovsyngende sprog fra gammel tid folkeligt, sådan at det kan lyde som vores sprog i menigheden her og nu.

C. Kort analyse af nogle latinske hymner $i$ Grundtvigs gendigtning til Sang-Vark I.

1. Conditor alme siderum/ Stjernernes Skaber og Himmelens Drot (SV 156)

Hymnen menes at stamme fra Ambrosius (en af de 18 ambrosianske hymner), men dette er diskutabelt. Den er næppe så gammel som 300-tallet. - Den har eksisteret i en tidligere dansk version, men Grundtvig har lavet en ny gendigtning. Grundtvigs kilde er iflg. Elbek J.H. Paulis Hymnologia Sacra (fra 1698). Man kan sige, at det er en almindelig hymne til Christus Pantokrator.

I dette tilfælde følger Grundtvig tæt originalen. Rytmisk kan vi måske lægge mærke til, at den faldende rytme, som hymnen har $\mathrm{i}$ sit indledende vers, men som den sidenhen ikke opretholder (en daktylisk indledning går successive over $\mathrm{i}$ en jambisk rytme, senere fuldt ud gennemført i Breviarium Romanum), beholder Grundtvig salmen igennem. Videre: den cæsur, som Grundtvig indfører, savnes i originalen.

Stroferne svarer nogenlunde til hinanden. Grundtvigsk er i 2. strofe den skjulte henvisning til, at Kristus-Ordet genopliver 
vores sprog. Derved går han dog glip af originalens dogmatisk mere klare donans reis remedium (hvor udtrykket reis i sig selv er meget interessant). I strofe 4 skal man nok notere, at originalens nutu subdita er stærkere (men også mere upersonligt) end Grundtvigs »Vogte med Flid på dit Vink og dit Nik«. Hvis dette er lidt banalt hos Grundtvig, synes jeg afgjort, at samme gælder om udtrykket »dit salige Smil« i strofe 6.

Endelig kan vi også lægge mærke til, at den kosmologiske strofe 5 i Grundtvigs strofe 5 personificeres stærkere. Den latinske tekst (som her sikkert ikke stammer fra Ambrosius) taler om en af Kristus oprettet kosmisk orden, den grundtvigske om et fællesskab i Kristus, hvor de kosmiske kræfter er inkluderede.

\section{Veni redemptor gentium/ Hedenskabets Frelser-Mand (SV} 157)

Også her drejer det sig om en hymne, tilskrevet Ambrosius. Den er meget mere dogmatisk end den første. Igen vælger Grundtvig den faldende rytme, medens originalen skifter (men dette hænger naturligvis sammen med, at den latinske poesi bygger på den mere bløde forskel mellem lange og korte stavelser, medens den danske bygger på trykforskelle). Dette har dog medført det uheldige valg af udtrykket »Hedenskabet« fremfor originalens »Hedningerne «.

Det drejer sig her om en inkarnationshymne. Samtidig er der en klar forskel: den latinske tekst handler om et bestemt led i trosbekendelsen, nemlig inkarnationens mysterium, medens Grundtvigs gengivelse svinger mellem det dogmatiske og det rent poetiske.

Som en kuriositet hos Grundtvig kan man lægge mærke til udtrykket i strofe 1: „Så 'eenbaaren' er Guds Ord/ Som i Himmel, saa paa Jord «. Den traditionelle fortolkning af »énbåren« er vel, at Gud Fader kun har denne Søn, men Grundtvig fortolker det sådan, at som Faderen alene føder Sønnen i evigheden, så føder Maria alene Sønnen i tiden.

Slående er, at det i den latinske tekst i strofe 1 forekommende udtryk Talis partus decet Deum (sådan fødsel er Gud værdig), klassisk og stærk, savnes hos Grundtvig. Ellers svarer strofe 
2 nogenlunde til strofe 2 hos Grundtvig, men forskellen er betydelig: Medens den latinske tekst taler om, at Guds Ord blev kød, ikke ved mands sæd, men ved en mystisk avlelse (af Helligånden er her underforstået), og at jomfrudommen blev bevaret, med en antydet henvisning til jomfruens dyd (i strofe 3), hæfter Grundtvig sig åbenbart ved, at Maria bevarede engelens ord i sit hjerte og at dette betød, at »Livsens Frugt« og »Guds Ord« faldt sammen. Her er Grundtvig igen meget specifik, og man kan spørge sig, om han ikke også er spiritualiserende.

I strofe 4 har vi igen en vigtig forskel. Den latinske tekst antyder brudgommen, der går ud af sit kammer; Grundtvig taler mere direkte om opstandelsen, dog med samme association. Hos Grundtvig dominerer billedet af solen, der stiger op af havet som parallel til Kristus, som stiger op af himmelens hav (inkarnationen) men også af dødens hav (opstandelsen). Det sammenholdende billede er Helten. Dette svarer i den latinske tekst til gigas, men det betones i stedet for denne gigant som sådan dogmatisk - ud fra den dobbelte natur.

Den latinske strofe 5 er formalistisk og spiller med ordene Egressus/Regressus resp. Excursus/Recursus. Grundtvig er svagere her, men har det dog med. I strofe 6 noterer vi en klar lighed, men den stærke latinske formulering Infirma nostri corporis/ Virtute firmans perpetim (igen et typisk ordspil) gengives med det svagere men mere nærgående: „Gav til Blod os Livets Saft«.

Lad os til sidst se lidt nærmere på strofe 7. Forholdet mellem Grundtvig og den latinske tekst er her vanskeligt. Begge taler om krybben, begge taler om troen. Men siger de det samme? Grundtvig har forandret de latinske indikativer i de første linier til spørgsmålssætninger. Han går ud fra, at Krybben stråler ligesom natten og besvarer spørgsmålet om hvorfor med, at Kristus vil være »Troens Morgen rød«. Sidstnævnte svarer til den latinske teksts formulering: fideque iugi luceat. Måske vil de to tekster bare sige det samme: lyset og troen kommer sammen, men sådan at Grundtvig snarere vil fremhæve, at Krybben (som for ham kryptisk er Guds Ord) kun stråler i lyset af den tro, som ikke er vores men Kristi. Strofe 8 hos Grundtvig sammenfatter: »Maria Mø« kommer tilbage (i den latinske tekst gentages det mere formelle natus de virgine). Men hvad betyder i sammenhængen det grundtvigske kodeord: »Jordens Lilje-Vand«?

Vi springer nu hurtigt over til næste salme: 
3. Puer natus in Bethlehem/ Et barn er født $i$ Bethlehem (SV 163).

Jeg har allerede næunt den som et eksempel på den latinske hymnetraditions tiltrækkende bibelske naivisme. Grundtvig følger forlægget forholdsvis tæt. Hos Grundtvig må man opfatte dette som en sang, som børn kan synge med på. Der er en bevidst barnlighed i hans gengivelse: »Lege Jul i Himmel-By« og »Stjerne-Tæpper lyseblaa«, der for mig at se, er pekoralistisk og som selvfølgelig savnes i den latinske teskt, som til gengæld tager vigtige dogmatiske ting op: f. eks. Peccato sed dissimilis (som Grundtvig ikke nævner) og Deo et sibi similes (som Grundtvig gengiver med det simplere »Gjør os til Guds Børn med sig «). Som helhed er der dog ingen teologiske problemer mellem Grundtvig og den latinske tekst.

4. Vexilla regis prodeunt/ Lad vaie højt vort Konge-Flag (SV 228)

Den latinske tekst gælder for at være af Venantius Fortunatus (f. ca. 530, død som biskop i Poitiers i Frankrig ca. 600). Hymnen har været sunget på Langfredag, på "Korsets genfindelsesfest « og »Korsets ophøjelsesfest « i den katolske kirke. Liturgisk har den været stærkt knyttet til ombærelsen af Hostien, påpeger Tårup. ${ }^{11}$ Et grundlæggende spørgsmål er, hvad »fanerne« (vexilla) - NB pluralis - egentlig henviser til: Er det til korset som sådant, og $\mathrm{i}$ hvert fald er det $\mathrm{i}$ den latinske tekst korset, som er hovedperson? Hurtigt glider korsbilledet over i andre: hostia, arbor, lignum, etc. Denne forskydning indebærer, at billedet af korset som livstraet snarest dominerer.

Også i Grundtvigs gengivelse sker en sådan forskydning, men billedet af korsets banner gentages i sidste strofe på en sådan måde, at koncentrationen omkring korset som sådant erstattes af opmærksomheden på de kristne som en hær, samlet under et flag. Dannebrogs-associationerne er helt klare i denne salme.

Lad mig endnu en gang understrege en stemningsforskel mellem teksterne. Den latinske tekst er en from betragtelse af korsets mysterium, med en beskrivelse af, hvad korsest er. At det 
beskrives som et banner, kan knyttes til, at hymnen har været brugt $\mathrm{i}$ forbindelse med processioner på de store korsdage. Hos Grundtvig tales også om korsets træ, men da korsfæstelsen betragtes - på typisk grundtvigsk, og østkirkelig vis - som en heltesejr, bevares assosciationerne til en krig, som vi er trukket med ind i. I strofe 6 er netop »Korsfæstelsen af Synd og Død« en »Helte-Daad til Livet«. Her kan vi også slå den for Grundtvig karakteristiske kontrastering Liv/Død fast, som han fandt støtte for hos Irenæus. Det er altså to meget forskellige grundvisioner, som her kommer til udtryk, selv om gendigtningen igen følger originalen forholdsvis tæt.

\section{Salve crux arbor/ Hil dig vor fane (SV 230)}

Den latinske tekst er af Adam af Sct. Victor (født i Vestfrankrig omkring år 1100), som var knyttet til Augustinerklostret Sct. Victor i nærheden af Paris.Han tilhørte samme tradition som de berømte Hugo og Richard af Sct. Victor. (For Grundtvig havde det sikkert ingen afgørende betydning, hvem der var forfatter til de forskellige hymner. Han må have set dem alle, i denne sammenhæng positivt, som repræsentanter for »den latinske menighed «.)

Her har vi et eksempel på, hvor frit Grundtvig kunne forholde sig til en tekst. Den latinske tekst begynder med billedet af korset som livets træ (et klassisk symbol) og udfolder derefter en hel emblematik med mange elementer: dels dem, som direkte fortolker korset, hvor fanen kommer ind, men kun som et billede, sammen med tronen og alteret (thronus et ara), senere følger så lignum (som knyttet til arbor), dels de betegnelser, som er relaterede til, hvad korset betyder for os: libra, sceptrum, virga potentiae, belli robur og palma gloriae samt frelsessymbolerne scala, ratis og tabula. Desuden udfolder den latinske tekst $\mathrm{i}$ strofe 5 korsets kosmiske karakter gennem henvisning til de fire himmelstrøg og til dets længde, bredde, højde og dybde som et kvadrat, som frelser verden sub quadri figura.

Af alt dette bruger Grundtvig kun én ting: korset som flag eller banner (med en antydning om korset som træ). Derfor knytter han til ved den latinske teksts lidt pludselige påmindelse 
om Konstantins sejr i korsets tegn (som den latinske tekst $\mathrm{i}$ øvrigt udvider med historiske detaljer).

Tendensen i SV 228 fremtræder meget stærkere her. Dette viser sig derved, at opmærksomheden retter sig mod korset som samlingspunkt for de kristne. Samtidig begrænses Konstantins betydning i strofe 3's sidste del. Heri ligger næsten en kritik af Eusebius' tendens til at forstå Konstantins sejr som en indledning til Gudsriget.

Vi vil nu gå hurtigt over til den berømte hymne:

\section{Stabat mater dolorosa/ Under korset stod med smerte (SV 231)}

Denne hymne er skrevet af Jacoponi da Todi fra 1200-tallet. Det drejer sig om et fantastisk digt, som har fundet vejen ind $i$ selve Missale Romanum. Jo mere man læser det, jo mere begejstret bliver man, selv om der er enkelte steder, hvor rutinen tager over fra den oprindelige poetiske følelse.

Fra begyndelsen kan vi nok slå fast, at Grundtvigs gengivelse ikke er på højde med originalen. Teologisk afgørende er følgende: I den latinske tekst står Maria i centrum, og det er hendes lidelse, der vinder vores medlidelse, og derigennem lærer vi at forstå Kristi lidelse for vores skyld. Hos Grundtvig fremhæves evangelisk - at Maria selv bliver frelst ved Kristi lidelse og død sammen med os andre. I den latinske tekst bliver Maria genstand for bøn, men sådan er det ikke hos Grundtvig.

Imidlertid føjer Grundtvig to ting til, som ikke findes i den latinske tekst. Den første er associationen mellem Maria og kirken (denne forbindelse er dog $\mathrm{i}$ og for sig katolsk). Den anden ting er henvisningen til Johannes, den discipel, som Jesus elskede. Jesus trøster sin mor $\mathrm{i}$ hendes bedrøvelse ved at give hende Johannes som hende søn. Han dør forsonende også for hende, men hans barmhjertighed viser sig allerede $i$, at han giver hende Johannes som sin erstatning. Desuden siger Grundtvig (strofe 4), meget dristigt, at Johannes ikke vil dø. Altså: den døende søn bliver erstattet af en søn, der ikke vil dø. Heri ligger moderens trøst. Så flytter Grundtvig dette over til Kirken som moder, som har en »Guds søn« ved sin side (strofe 6). Her er den poetiske frihed gået vidt! 
Det vigtige er dog, at Grundtvig hele tiden hæfter sig ved moderhjertet. Det gør den latinske tekst ikke, idet den snarere fremhæver Marias stilling og går ud fra, at hun hører sit folks bønner (strofe 9). Hos Grundtvig er det modersmerten, der har fundet nåde.

\section{Salve mundi salutare/ Hil dig, Frelser og Forsoner (SV 232)}

Denne tekst er skrevet af Arnoulf af Louvain (Grundtvig troede, at den var skrevet af Bernhard af Clairvaux selv). Arnoulf var dog en bernhardin og blev abbed af cistercienserklostret Villers i det nuværende Belgien. Det er den bernhardinske fromhed, der præger hans digtning.

Her er det lidt usikkert, hvilken latinsk tekst, Grundtvig har brugt. Selv siger han blot, at den bernhardinske tekst er »frit oversat«. Det der er fælles, er selvfølgelig opmærksomheden på den korsfæstede Kristus. Iflg. Tårup går Arnoulf nedefra og op: han er meditativt opmærksom på fødderne, knæene, hænderne, siden og ansigtet (åsynet); men det passer dog ikke til den latinske tekst, som Grundtvig sandsynligvis har brugt. ${ }^{12}$ Også i den danske oversættelse, som han gengiver, har Tårup kun fødderne, hænderne og ansigtet med. I den tekst, som jeg er gået ud fra, går blikket ikke nedefra og opad, men starter med hovedet og fortsætter derefter med siden og ender med fødderne. Hos Grundtvig har vi i strofe 2 ansigtet, i strofe 3 fødderne og i strofe 8 siden. Grundtvigs forlæg må have haft den samme orientering.

Overensstemmelserne er ikke så store, men de findes. Grundtvig har faktisk i dette tilfælde flere dogmatiske formuleringer: »Korsets Død i vores Sted« (strofe 6), blodfloden som kan tvætte blodskylden af (strofe 9), som dog svarer til strofe 6 i den latinske tekst: Ex quo scatet fons cruoris/ qui corda lavat sordida »Du betalde Syndens Sold« (strofe 11). Men som sagt ved vi ikke, hvilken tekst Grundtvig har brugt.

Vi går så til en meget specifik påskesalme: 
8. Mane prima sabbati/ $O$, saligt dog det Øine-Par (SV 236)

Denne tekst fra højmiddelalderen er anonym, men den har åbenbart haft en stor betydning. Vigtigt er, at den fokuserer på Maria Magdalene som det første øjenvidne til opstandelsen. Videre gælder, at teksten parallelliserer Maria Magdalene med Maria, Jesu moder. Der er ligheder, men der er ikke mindst forskelle mellem dem. Grundtvig fastholder denne dobbelthed.

Men der er også store forskelle mellem Grundtvigs tekst og den latinske. For Grundtvig drejer det sig om to kvinder simpelthen. Også han betoner dog forskellen mellem de to. Maria, Jesu moder, kaldes i strofe 4 »Maria Jomfru-Viven «, medens Maria Magdalene betegnes som »Synderinde«, med tilføjelsen »til vor Trøst « - et evangelisk træk. I den latinske tekst kaldes Maria Magdalene peccatrix (uden Grundtvigs tilføjelse!), medens Maria, Jesu moder forsynes med prædikatet mundi imperatrix (en mariologi, som Grundtvig selvfølgelig tager afstand fra). Dog får vi at vide, at Maria Magdalene ligner Kristi moder, men er hende underordnet $\mathrm{i}$ rang (strofe $9 \mathrm{~b}$ ).

Grundtvigs specifikke bidrag til sammenligningen kommer i sidste strofe, som igen viser hans genialitet og dristighed: "Hun fødte Ham, som Liv kom fra/ Du Skabningens Halleluja «. Så dristig er den latinske tekst ikke, som dog stiller os på niveau med Maria Magdalene (se strofe 13).

Næste salme er Adam af Sct. Victors meget smukke

\section{Mundi renovatio/ Verdens Igienfødelse (SV 237)}

Tårup forestiller sig, at munken Adam sidder foran sit åbne vindu en forårsdag og ser, hvordan livet kommer tilbage, og knytter dette sammen med påskebegivenheden. Så bliver hymnen til. ${ }^{13}$ På samme måde kan man forestille sig, at Grundtvig har oplevet forårets fornyelse. Men for begge digtere står det klart, at den virkelige, dybeste fornyelse, den står påsken for: den fra død til liv under evighedens synsvinkel.

Grundtvig kommer i sin gendigtning egentlig meget tæt på den latinske tekst. Der findes nogle specifikke grundtvigske detaljer, der dog ikke helt savner støtte i den latinske tekst: 
»Sjunge Paaske-Psalmer« (strofe 1), »Fugle-Choret « (strofe 2) og den specifikke drejning om Cheruben i strofe 5: »Olie-Green med Palme-Blad,/ Vinker os til Haven «.

Vigtigt er, at begge tekster taler om de fire elementer: ild, luft, vand og jord, og at de er med i fornyelsen. Men Adams kosmologi er meget mere filosofisk, medens Grundtvigs er naturpoetisk. For Adam er det afgørende, at kosmos' balance vedligeholdes. Dette optager ikke Grundtvig. Han personificerer naturen, sådan som den er, med lovsangen til opstandelsens Herre. Forsoningsgerningen som en sejr (strofe 4) kommer her tilbage hos Grundtvig, men dette har støtte i den latinske tekst (strofe 4): Gelu mortis solvitur/ Princeps mundi tollitur/ et eius destruitur..., selv om dette også er mere upersonligt. Det drejer sig $\mathrm{i}$ det hele om en kosmisk begivenhed.

Næste tekst kunne vi opholde os ved meget længe på grund af alle de mere eller mindre skjulte bibelallusioner, som den indeholder:

\section{Zyma vetus expurgetur/ Gamle Surdei! ud af Huset!} (SV 238)

Vi er også her hos Adam af Sct. Victor. Udgangspunktet er 1. Kor. 5,7: »Rens den gamle surdej ud, for at I kan være en ny dej, da I jo er usyrede...«. I den latinske tekst giver dette anledning til en typologisk bibeludlægning, hvor gammeltestamentlige firgurer bruges som typer for antitypen Kristus. Udgangspunktet er hentet fra Hebr. 10,1 og Kol. 2,17 og kommer i den latinske tekst til udtryk på følgende måde i strofe 4: Lex est umbra futurorum/ Christus finis promissorum,/ Qui consummat omnia. På en karakteristisk måde gør Grundtvig det hele personligt og knytter indirekte til ved tanken om det levende Ord (strofe 3): "Skyggeviis alt Moses-Haanden/ Har betegnet Herrens Daad,/ Virkelig og Christus-Aanden/ Aabenbarer Himlens Raad«. I en vis udstrækning kan vi se, at Grundtvig spiritualiserer. Hvor den latinske tekst simpelthen noterer overensstemmelser som frelseshistoriske facts, indfører Grundtvig vores egen tilgang til disse ting gennem Ånden, som oplyser os. Dette medfører, at 
han på en slående måde bliver mere optaget af de gammeltestamentlige personer end af den typologiske overensstemmelse.

Tydeligst bliver dette, hvis man sammenligner den latinske teksts strofe 5b om Josef: Ioseph exit de cisterna/ Christus redit ad superna med Grundtvigs strofe 6, der er væsentlig forskellig herfra.

I øvrigt: Af alle de eksempler, som den latinske tekst har, vælger Grundtvig nogle få. Interessant er, at også han har Samson med. Det vigtige for os er dog forskellen mellem Adams mere formalistisk-typologiske adgang og Grundtvigs friere personlige.

Måske skal vi også notere, at den henvisning til nadveren, som vi i den latinske tekst først møder i strofe 13, hos Grundtvig findes allerede i den første strofe. Vi kan tilføje, at dette er typisk for Grundtvigs måde at gendigte. Han har adgang til hele indholdet, men former det selvstændigt.

Om næste tekst kan vi fatte os meget kort:

11. Laus tibi Christe, qui pateris/ Den bitre d $\phi d$ Dig trangde (SV 271)

Den latinske tekst er anonym, selv om Grundtvig mener, at den er fra Palladius. Den latinske tekst består af to strofer, hvoraf nr. 2 er mariologisk. Grundtvig har lavet indholdet om til tre strofer, men har udeladt den mariologiske del, hvor der tales også om Marias forbøn.

Vi kan så gå videre til en pinsehymne:

12. Beata nobis gaudia/ Tider skifte, atter kom (SV 346)

Den latinske tekst er anonym, fra den tidlige middelalder. Den beskriver pinsens under og dets betydning for os. Det er på én måde en temmelig naiv tekst. Grundtvig bruger sin gendigtning til at udtrykke noget af sin egen forståelse om Ordet på folkemål. 
Grundtvigs strofe 3 er på den måde typisk, specielt de to første vers. Henvisningen til påsken $\mathrm{i}$ den latinske strofe 4 savnes hos Grundtvig. Grundtvigs strofe 4 svarer til den latinske strofe 5, selv om de er meget forskellige. Den latinske strofe 6 må have glædet Grundtvig med dialektikken mellem dudum og nunc. For Grundtvig er hele perspektivet et nu-perspektiv, men også den latinske tekst bevæger sig således hen imod nuet. Derimod tager Grundtvig ikke temaet med synden op. For ham er det afgørende, hvad Ånden gør nu, når den lærer os at lovsynge. Men han falder $\mathrm{i}$ de to sidste linier igen godt sammen med den latinske ordlyd: Et da quieta tempora.

\section{Urbs beata Ierusalem.../ På Jerusalem det ny (SV 349)}

Dette er en kirkehymne fra tidlig middelalder, og forfatteren er ukendt. Dens tema er kirken som det nye Jerusalem, grundlagt $i$ himmelen og bestående af levende stene. Dette Jerusalem er en storby, eller måske oven i købet en stat: sacra et dilecta civitas siger den latinske tekst i strofe 6 .

Grundtvig betoner $\mathrm{i}$ sin gendigtning menneskene mere end selve byen. Dog er han i strofe 6 mere romantisk og kan ikke lade være med at påminde om sang og om »Strenge-Leg og Orgel-Klang «, noget som den latinske tekst selvfølgelig ikke har med. Dog er der en klar bibelsk overensstemmelse om Kristus som hjørnestenen: jævnfør det latinske Angulare fundamentum lapis missus est med Grundtvigs »Stadens Grundvold fast og reen,/ Kirkens Hoved-Hjørnesteen.../ Det er Herren Jesus Christ «.

Vi afslutter nu denne gennemgang med en tekst, som stammer fra selveste Thomas ab Aquino:

\section{Pange lingua gloriosi.../ Sin Eenbaarne Gud Hengivet (SV 354)}

Grundtvig betegner den tekst som en Altergangs-Sang, og det er korrekt, men den har naturligvis også været brugt i forbindelse med hostietilbedelse. Forskellen mellem den latinske tekst og 
Grundtvigs gendigtning (som ikke er blandt hans bedste) er forholdsvis stor. Mærkeligt er, at henvisningen til Kristi indstiftelse af nadveren savnes hos Grundtvig, som i stedet for på en karakteristisk måde lægger hovedvægten ved Ordet, som bliver $\mathrm{k} ø \mathrm{~d}$ i brød og vin og som er »Evigt Liv« (strofe 3).

Thomas er dogmatisk, Grundtvig mere hymnisk og henvisende. Dog forenes de på en spændende måde i en slags sola fideteologi: Thomas siger: Ad firmandum cor sincerum sola fides sufficit (man kan ikke se, man må tro på Kristi reale nærvær), og Grundtvig siger: »Troen altid faar det Hele«.

Måske er dette den bedste afslutning man kunne tænke sig på denne fragmentariske redegørelse for nogle af Grundtvigs gendigtninger af latinske hymner.

\section{Noter}

1 Se J. Elbek: „Grundtvig og de latinske hymner«, Grundtvig Studier 1959 samt J. Pedersen: Fra Augustin til Johs. V. Jensen. Essays og afhandlinger, København 1991, s. 165-203.

2 J. Elbek: Grundtvig og de graeske salmer. København 1960.

3 Kr. Tårup: Grundtvigs påskesalmer. En redegørelse for ti salmer, København 1937.

4 Chr. Thodberg: "Grundtvig som salmedigter «, i Chr. Thodberg-A. Pontoppidan Thyssen (red.): Grundtvig og grundtvigianismen $i$ nyt lys. Hovedtanker og udviklingslinier fra de senere års Grundtvigforskning, Arhus 1983, s. 163196.

5 N. Thomsen: „Grundtvig i oldkirkens spejl«, ibid. s. 197-209 og J.H. Schjørring: Grundtvigs billedsprog og den kirkelige anskuelse, Frederiksberg 1990.

6 Elbek, art. cit., s. 10.

7 Elbek, art. cit., s. 12.

8 Ibid., s. 14.

9 Loc. cit.

10 Se Thodberg, art. cit., s. 176.

11 Se Tårup, op. cit., s. 33.

12 Se ibid., s. 13.

13 Ibid., s. 165. 


\section{Følgende latinske tekster har været brugt til ana- lysen ovenfor:}

(Forlægget til de kommenterede tekster 3 og 6 er dog ikke gengivet her)

1. Conditor alme siderum Aeterna lux credentium Christe redemptor omnium, Exaudi preces supplicum.

Qui condolens interitu Mortis perire sæculum, Salvasti mundum languidum Donans reis remedium.

Vergente mundi vespere Uti sponsus de thalamo, Egressus honestissima Virginis matris clausula.

Cuius forti potentiae, Genu curvantur omnia, Coelestia, terrestria, Fatentur nutu subdita.

Occasum sol custodiens, Luna pallorem retinens, Candor in astris relucens Certos observat limites.

Te deprecamur Hagie, Venture index sæculi, Conserva nos in tempore Hostis a telo perfidi.

2. Veni redemptor gentium, Ostende partum virginis, Miretur omne sæculum: Talis partus decet Deum.
Non ex virili semine, sed mystico spiramine Verbum Dei factum est caro,

Fructusque ventris floruit.

Alvus tumescit virginis, Claustra pudoris permanent,

Vexilla virtutum micant

Versator in templo Deus.

Procedens de thalamo suo, Pudoris aula regia, Geminæ gigas substantiæ Alacris ut currat viam.

Egressus eius a patre, Regressus eius ad patrem, Excursus usque ad inferos, Recursus ad sedem Dei.

Aequalis eterno patri Carnis tropaeo accingere, Infirma nostris corporis Virtute firmans perpetim.

Præsepe iam fulget tuum Lumenque nox spirat novum,

Quod nulla nox interpolet Fideque iugi luceat.

Gloria tibi Domine, Qui natus es de virgine Cum patre et sancto spiritu In sempiterna sæcula. 
4. Vexilla regis prodeunt, Fulget crucis mysterium Quo carne carnis conditor

Suspensus est patibulo.

Confixa clavis viscera, Tendens manus vestigia, Redemtionis gratia

Hic immolata est hostia.

Quo vulneratus insuper Mucrone diro lanceae, Ut nos lavaret crimine Manavit unda sanguine.

Impleta sunt quae concinit, David fideli carmine Dicens: in nationibus Regnavit a ligno Deus.

Arbor decora et fulgida

Ornata regis purpura, Electa digni stipite

Tam sancta membra tangere.

Beata cuius brachiis

Pretium pependit sæculi, Stateri facta sæculi Prædamque tulit tartaris.

5. Salve crux arbor vitae preclara, Christi vexillum, thronus et ara.

O crux profanis tortor et ruina, tu christianis virtus es divina, salus et victoria.
$\mathrm{Tu}$ properantis contra Maxentium, tu proeliantis iuxta Danubium Constantini gloria.

Favens Heraclio perdis cum filio Cosdroe profanum. In hoc salutari ligno gloriari decet christianum.

Crusis longum, latum, subcime, profundum, sanctis propalatum, Quadrum salvat mundum, Sub quadri figura.

Medicina vera Christus in stratera crucis est distractus pretiumque factus solvit mortis iura.

Crux est nostrae libra iustitiae, sceptrum regis, virga potentiae.

Crux coelestis signum victoriae, belli robur et palma gloriae.

Tu scala, tu ratis, tu crux desperatis, tabula suprema, tu de membris Christi decorem traxisti regum diadema. 
Per te nobis, crux beata, crux cruore consecrata, sempiterna gaudia det superna gratia.

7. Salve mundi salutare Salve, salve, Iesu care! Cruci tuae me aptari Vellem tibi me aequari, Da mihi tui copiam.

Salve Iesu Rex Sanctorum, Spes votiva peccatorum, Crucis ligno, tanquam reus, Pendens homo, verus Deus; Caducis nutans genibus.

Quid sum tibi responsurus, Actu vilis, corde durus? Quid rependam amatori, Qui elegit pro me mori, Ne dupla morte morerer?

Salve Iesu, pastor bone, Fatigatus in agone, Qui per lignum es distractus,

Et ad lignum es compactus, Expansis sanctis manibus.

Salve caput cruentatum, Totum spinis coronatum, Conquassatum, vulneratum, Arundine ververatum, Facie sputis illita.

Salve latus Salvatoris, In quo latet mel ducoris, In quo patet vis amoris, Ex quo scatet fons cruoris, Qui corda lavat sordida.
Clavos, pedum plagas duras,

Et tam graves impressuras, Circumplector cum affectu, Tuo pavens in pectu, Tuorum memor vulnerum.

Dulcis Iesu, pie Deus! Ad te clamo, licet reus. Praebe mihi te benignum, $\mathrm{Ne}$ repellas me indignum De tuis sanctis pedibus.

Dum me mori est necesse, Noli mihi tunc deesse, In tremenda mortis hora, Veni Iesu absque mora, Tuere me, et libera.

Cum me imbes emigrare, Iesu care! tunc appare, $\mathrm{O}$ amator ampletende! Temet ipsum tunc ostende, in cruce salutifera.

8. Mane prima sabbati Surgens Dei filius Nostra spes et gloria:

Victo rege sceleris Rediit ab inferis Cum summa victoria.

Resurgentis itaque Maria Magdalena Facta est prænuntia.

Ferens Christi fratribus Eius morte tristibus Expectata gaudia. 
O beati oculi,

Quibus regem sæculi

Morte iam deposita

Primum est intuita.

Hæc est illa femina, Cuius cuncta crimina

Ad Christi vestigia

Eius lavit gratia.

Quae dum plorat et mens orat

Facto clamat quod cor amat Iesum super omnia.

Non ignorat, quem adorat, Quod precatur, iam deletur, Quod mens timet conscia.

O Maria, mater pia, Stella maris appellaris Operum per merita: Matri Christi coaequata, Dum fuisti sic vocata Sed honore subdita.

Illa mundi imperatrix, Ista beata peccatrix Laetitiae primordia Fuderunt in ecclesia.

Illa enum fuit porta, Per quem salus est exorta: Hæc resurgentis nuntia Mundum replet lætitia.

O Maria Magdalena, Audi vota laude plena, Apud Christum chorum istum Clementer concilia.
Ut fons summae pietatis, Qui te lavit a peccatis Servos suos atque tuos Mundet data venia: Amen dicant omnia.

9. Mundi renovatio Nova parit gaudia, Resurgento domino Conresurgunt omnia: Elementa serviunt Et auctoris sentiunt Quanta sint sollemnia.

Ignis volat nobilis, Et aer volubilis, Fluit aqua labilis, Terra manet stabilis, Alta petunt levia, Centrum tenent gravia, Renovantur omnia.

Coelum fit serenius, Et mare tranquillius, Spirat aura levius, Vallis nostra floruit. Revirescunt avida Recalescunt frigida Post quae ver intepuit.

Gelu mortis solvitur Princeps mundi tollitur Et eius destruitur In nobis imperium, Dum tenere voluit, In quo nihil habuit Ius amisit proprium.

Vita mortem superat, Homo iam recuperat, Quod prius amiserat Paradisi gaudium: 
Viam præbet facilem

Cherubim versatilem

Ut deus promiserat

Amovendo gladium.

10.Zyma vetus expurgetur

Ut sincere celebretur

Nova resurrectio:

Hæc est dies nostrae spei,

Huius mira vis diei

Legis testimonio.

Hæc Aegyptum spoliavit

Et Hebræos liberavit

De fornace ferrea:

His in arcto constitutis

Opus erat servitutis,

Lutum, later, palea.

Iam divinae laus virtutis

Iam triumphi, iam salutis

Vox erumpat libera:

Hæc est dies quam fecit dominus,

Dies nostri doloris terminus,

Dies salutifera.

Lex est umbra futurorum,

Christus finis promissorum, Qui consummat omnia:

Christi sanguis igneam

Hebetavit romphaeum

Amota custodia.

Puer nostra forma visus, Pro quo vervex est occisus, Vitae signat gaudium, Ioseph exit de cisterna, Christus redit ad superna Post mortis supplicium.
Hic dracones Pharaonis

Draco vorat, a draconis

Immunis malitia:

Quos ignitus vulnerat

Hos serpentis liberat

Aenei præsentia.

Anguem forat in maxilla

Christi hamus et armilla

In cavernam reguli

Manum mittit ablactatus

Et sic fugit exturbatus

Vetus hospes sæculi.

Irrisores Helisaei,

Dum conscendit donum die,

Zelum calvi sentiunt:

David aneptitius,

Hircus emissarius

Et passer effugiunt.

In maxilla mille sternit

Et de tribu sua spernit

Samson matrimonium,

Samson Gasae seras pandit

Et asportans portas scandit

Montis supercilium.

Sic de Iuda leo fortis

Fractis portis dirae mortis

Die surgit tertia

Rugiente voce patris

Ad supernæ sinum matris

Tot revexit spolia.

Cetus Ionam fugitivum, Verae Ionæe signativum, Post tres dies reddit vivum De ventris angustia:

Botrus Cypri reflorescit, Dilatatur et excrescit, Synagogae flos marcescit, et floret ecclesia. 
Mors et vita conflixere, Resurrexit Christus vere et cum Christo surrexere Multi tester gloriae. Mane novum, mane lætum, Vespertinum tergat fletum, Quia vita vicit letum: Tempus est laetitiae.

Iesu victor, Iesu vita, Iesu vitae via trita, Cuius morte mors sopita, Ad paschalem nos invita Mensam cum fiducia. Vive panis, vivax unda Vera vitis et fecunda: Tu nos pasce, tu nos munda, Ut a morte nos secunda Tua salvet gratia.

\section{Laus tibi Christi qui pateris} in cruce pendens pro nobis miseris, cum patre regnas in coelis, nos reos salva in terris.

Kyrie eleison.

O Maria, dei genitrix, pium fer auxilium pro nobis miseris, ne nos damnemur cum impiis,

sed ut salvemur cum beatis. Kyrie eleison.

\section{Beata nobis gaudia} Anni reduxit orbita, Cum spiritus paraclitus Effulsit in discipulos.
Ignis vibrante lumine Lingua figuram detulit, Verbis ut essent proflui et caritate fervidi.

Linguis loquuntur omnium, Turbae pavent gentilium, Musto madere deputant, Quos spiritus repleverat.

Patrata sunt hæc mystice Paschae peracto tempore, Sacro dierum numero, Quo lege fit remissio.

Te nunc, Deus piissime, Vultu precamur cernuo; Illapsa nobis coelitus Largire dona spiritus.

Dudum sacrata pectora Tua replesti gratia, Dimitte nun peccamina et da quieta tempora.

13. Urbs beata Hierusalem, dicta pacis visio, Quae construitur in coelis vivis ex lapidibus

Et angelis coornata ut sponsata comite.

Nova veniens e coelo nuptiali thalamo

Præparata ut sponsata copulata domino, Plateae et muri eius ex auro purissimo.

Portae nitent margaritis adytis patentibus 
Et virtute meritorum illuc introducitur

Omnis qui pro Christi nomine hoc in mundo premitur.

Tunsionibus, pressuris expoliti lapides

Suis coaptantur locis per manum artificis,

Disponantur permansuri sacris aedificiis.

Angulare fundamentum lapis Christi missus est

Qui compage parietim in utroque nectitur,

Quem Sion sancta suscepit, in quo credens permanet.

Omnis illa Deo sacra

et dilecta civitas

Plena modulis in laude et canore iubilo,

Trinum Deum unicumque cum favore prædicat.

Hoc in templo, summe Deus, exoratus adveni

Et clementi bonitate precum vota suscipe,

Largam benedictionem hic infunde iugiter.

Hic promereantur omnes petita accipere

Et adepta possidere cum sanctis perenniter, Paradisum introire, translati in requiem.
14. Pange lingua gloriosi corporis mysterium

Sanguinisque pretiosi, quem in mundo pretium

Fructus ventris generosi, rex effudit gentium.

Nobis natus, nobis datus ex intacta virgine

Et in mundo conversatus, sparso verbi semine,

Sui moras incolatus miro clausit ordine.

In supremæ noctæ coenæ recumbens cum fratribus Observata lege plene cibis in legalibus,

Cibum turbæ duodenæ se dat suis manibus.

Verbum caro, panem verum verbo carnem efficit, Fitque sanguis Christi merum, et si sensu deficit Ad firmandum cor sincerum sola fides sufficit.

Tantum ergo sacramentum veneremur cernui

Et antiquum documentum novo cedat ritui:

Præstet fides supplementum sensuum defectui.

Genitori genitoque laus et iubilatio

Salus, honor, virtus quoque sit et benedictio

Procedenti ab utroque compar sit laudatio. 